\title{
Streptozotosin kaynaklı diyabetik sıçanlarda Arum rupicola'nın in vivo antioksidan potansiyeli
}

\author{
Necati ÖZOK*, İnan GÜNEŞ \\ Yüzüncü Yll Üniversitesi, Biyoloji Bölümü, Van \\ (ORCID: 0000-0002-6733-211X) (ORCID: 0000-0001-8651-689X)
}

\begin{abstract}
$\ddot{O} \mathbf{z}$
Diabetes mellitus, dünya popülasyonunun azımsanmayacak bir kesimini etkileyen metabolik bir hastalıktır. Arum rupicola, Doğu ve Güneydoğu Anadolu'da, halk hekimliğinde diyabetin tedavisi için kullanılmaktadır. Bu çalışma, Arum rupicola'nın streptozotosin (STZ) ile oluşturulan diyabetik sıçanlarda toprak üstü kök ve gövde liyoflize ekstresinin oksidatif stres belirteçleri üzerine etkisini değerlendirmek için tasarlanmışırı. Çalışmanın deneysel modellemesine göre, toplam 36 adet erkek sıçan rastgele altı gruba ayrıldı. İlk grup, normal kontrol (NK), ikinci grup, streptozotosin (STZ) ile deneysel diyabet oluşturuldu (DK). Üçüncü grup, diyabet+akarboz (DAK) deneme süresince verildi. Dört, beş ve altıncı gruplardaki sıçanlar STZ ile diyabet oluşturulduktan sonra sırasıyla 100, 200 ve $400 \mathrm{mg} / \mathrm{kg}$ (DAR: Diyabet+Arum ekstresi: DAR 100, DAR 200, DAR $400 \mathrm{mg} / \mathrm{kg}$ ) doz aralığında Arum rupicola liyoflize ekstresi gavaj yolu sıçanlara verildi. Bu çalışmada, antioksidan savunma sistemi unsurlarından olan süperoksit dismutaz (SOD), glutatyon peroksidaz (GPx), katalaz (CAT) aktivitesi ile non-enzimatik antioksidan olan glutatyon (GSH)'un düzeylerinin ölçümleri gerçekleştirildi. Ayrıca, lipit peroksidasyonun (LPO) son ürünü olan malondialdehit (MDA) seviyeside belirlendi. Diyabetik gruplarda, uygulama dozlarının tümünde SOD, GPx ve CAT ve GSH düzeylerindeki azalışlar normal kontrol (NK) grubuna göre anlamlı bulundu. Ancak eritrosit ve karaciğer dokularında lipit peroksidasyonu sonucu oluşan MDA'in düzeyinde görülen azalma normal kontrol ve diyabetik kontrol gruplarına göre anlamlı bulundu $(\mathrm{p} \leq 0.05)$. Diğer yandan, beyin dokusu DAR3 grubunda ve böbrek dokusu DAR1, DAR2, DAR3 gruplarında artan MDA düzeyleri istatiksel olarak anlamlı bulunmuştur. Bitki ekstresi uygulanan diyabetik gruplarda, farklı dokularda belirlenen değişken SOD, GPx ve CAT aktivite ve GSH'un ölçümleri istatistiksel olarak anlamlı bulundu ( $\leq \leq 0.05$ ). Sonuç olarak, diyabetik sıçanlarda oksidatif stresin etkileri karşısında Arum rupicola ekstresinin doza bağlı dokudan-dokuya farklılık gösteren antioksidatif etkiye sahip olduğu tespit edilmiştir.
\end{abstract}

Anahtar kelimeler: Arum rupicola, Antioksidan, Oksidatif stres, Siçan

\section{In vivo antioxidant potential of Arum rupicola in streptozotocin-induced diabetic rats}

\begin{abstract}
Diabetes mellitus is a metabolic disease that affects a significant portion of the world population. Arum rupicola is used in eastern and southeastern Anatolian for the treatment of diabetes in folk medicine. This study was designed to evaluate the effect of Arum rupicola on oxidative stress markers of the above ground root and stem lyophilized extracts in diabetic rats with streptozotocin (STZ). According to the experimental modeling of the study, a total of 36 male rats was randomly divided into six groups. The first group consisted of normal control (NK) and second group of streptozotocin (STZ) experimental diabetes (DK). The third group was given standard drug+acarbose (DAK) during the trial period rats in the four, five and sixth groups were given the rats with a dose range of 100, 200 and $400 \mathrm{mg} / \mathrm{kg}$ (DAR 100, DAR 200, DAR $400 \mathrm{mg} / \mathrm{kg}$ ). In this study, the levels of antioxidant defense system superoxide dismutase (SOD), glutathione peroxidase (GPx), catalase (CAT) activity and nonenzymatic antioxidant glutathione (GSH) levels were measured. In addition, malondialdehyde (MDA) content of the final product of lipid peroxidation (LPO) was measured. In diabetic groups, decreases in SOD, GPx and CAT and GSH levels were found to be significant compared to normal control group. However, the decrease in MDA levels in erythrocyte and liver tissues as a result of lipid peroxidation was found to be significant compared
\end{abstract}

*Sorumlu yazar: necatiozok@yyu.edu.tr

Geliş Tarihi:01.04.2019 Kabul Tarihi: 21.04.2019 
to normal control and diabetic control groups $(\mathrm{p} \leq 0.05)$. On the other hand, increased MDA levels were found to be statistically significant in the DAR3 group of brain tissue and in the DAR1, DAR2, DAR3 groups of kidney tissue. Variable SOD, GPx and CAT activity and GSH measurements in different tissues were statistically significant in diabetic group $(\mathrm{p} \leq 0.05)$. As a result, Arum rupicola extract has been shown to have an antioxidative effect on tissue-to-tissue in response to the effects of oxidative stress in diabetic rats.

Keywords: Arum rupicola, Antioxidant, Oxidative stress, Rat

\section{Giriş}

Diabetes mellitus yüksek kan glikozu değerleri ve şeker, lipit ve protein metabolizmasındaki bozukluklarla tanımlanan metabolik bir hastalıktır [1]. Küresel popülasyonların \% 6,3'den fazlasının diabetes mellitus hastalığı ile muzdarip olduğu tahmin edilmektedir [2]. Kronik olarak birçok hastalığın (Hiperglisemi, anjiyopati, nöropati, retinopati, zayıflamış antioksidan savunma sistemi, metabolik bozukluklar ve lipit profilindeki değişimler gibi) ana nedeni olarak kabul edilir [3]. Hiperglisem ile bağlantılı olan oksidatif stresin diyabetik komplikasyonların en önemli sebebi olduğu rapor edilmiştir [4]. Reaktif Oksijen Türleri (ROS) üretiminde mitokondriyal metabolizmanın rolü vardır. Başka bir deyişle mitokondriler, yalnızca hücresel enerji üreten organeller değillerdir aynı zamanda reaktif oksijen türlerinin üretim merkezleridir [5-7]. Oksidatif strese bağlı artan ROS üretiminin, enerji dengesinde ciddi bozukluklara neden olduğu bildirilmiştir. Bu durumda hücre antioksidan savunma sistemi ROS'un yıkıcı etkilerini hızlı bir şekilde etkisizleştirmek zorundadır. Aksi takdirde zayıflamış antioksidan sistemi ve aşırı üretilen ROS radikalleri nükleik asitler, proteinler, lipitler ve karbonhidrat gibi makro molekülleri tahrip ederek hücre hasarına sebep olurlar [8]. İn vivo enzimatik ya da enzimatik olmayan endojen antioksidanlar ROS radikallerinin etkilerinin nötralizesinden sorumludurlar. Ancak hiperglisemi ve hiperlipidemi gibi komplikasyonların ROS üretiminde artışa neden olarak antioksidan enzimlerin reaksiyonlarını olumsuz yönden etkilemekte ve sonuçta bu antioksidanların seviyelerinde bir azalmaya sebep olmaktadırlar. Bitki bazlı polifenoller, flavonoidler ve tanenler gibi bazı bileşenleri serbest radikallerden kaynaklanan hasarlara karşı antioksidan etki gösterdiği bildirilmiştir $[9,10]$.

Araştırma materyali Arum rupicola (yılanyastığı, yılanbiçağı, danayanağı) Arum cinsine ait çok yıllık yumrulu bitkilerdir. Toprak üstü gövde ve yaprakları pişirilerek sebze yemeği olarak yörede tüketilmektedir. Ayrıca bu bitki geleneksel tıpta (Doğu ve Güneydoğu Anadolu bölgesinde) diyabet, baş ağrısı, hemoroid gibi hastalıkların tedavisinde kullanılmaktadır [11, 12].

$\mathrm{Bu}$ araştırmada, halk arasında diyabet tedavisinde kullanılan Arum rupicola toprak üstü gövde ve yaprak ekstresinin diyabet kaynaklı oksidatif stres üzerindeki antioksidatif etkisinin araştırılması amaçlanmıştır.

\section{Materyal ve Metot}

\subsection{Ekstraksion}

Çalışma materyali Arum rupicola Boiss. var. virescens (Stapf.) P.C.Boyce, bitkisi Muş-Varto Köprücük Köyü'nden toplandı. Bitki teşhisi Van Yüzüncü Yıl Üniversitesi Fen Fakültesi Biyoloji Bölümünde (Dr. S. Mesut PINAR) gerçekleştirildi (No.164100). Bitki kök ve gövdesi gölge bir ortamda kurutuldu. Kurutulan materyal havanda toz haline getirildikten sonra 50 gr tartılarak $1000 \mathrm{ml}$ distile su ile karışmı hazırlandı. Karışım 24 saat dijital çalkalayıcıda çalkalandı sonra süzüldü ve süzüntü evaporatorde konsantre edildi. Süzüntü falkon tüplerine alınarak $-80^{\circ} \mathrm{C}$ 'de 48 saat bekletildi. Donmuş konsantre süzüntü liyofilizatör cihazında (Edwards, Fransa) $-51^{\circ} \mathrm{C}$ 'de ve 50 millitor basınç altında su içeriği tamamen uçuruldu. Ekstre daha sonra üzere $+4{ }^{\circ} \mathrm{C}$ 'de muhafaza edildi [13].

\subsection{Deney hayvanları}

Bu çalışmada, 200-350 g ağırlı̆̆ındaki 47 erkek Wistar albino sıçanı, Van Yüzüncü Yıl Üniversitesi Deney Hayvanları Ünitesinden satın alındı. Hayvanlar oda sıcaklığında $\left(25 \pm 1^{\circ} \mathrm{C}\right), 12$ saat aydınlık / karanlık 1şı periyodunda tutuldu. Beslenmelerinde gıda ve su'ya erişimleri ad libitum olarak 
gerçekleşti. Bu çalışma, Van Yüzüncü Y11 Üniversitesi Hayvan Deneyleri Yerel Etik kurulu tarafından onaylanmıştır (Protokol no: 2019/01).

\subsection{Akut toksisite testi}

Oral toksisite testi Organization for Economic Corporation and Development (OECD) rehberi 425'e göre yapıldı. Bu test için toksisite doz aralığ $2000,5000 \mathrm{ve} 10000 \mathrm{mg} / \mathrm{kg}$ değerleri seçildi. Bu rehbere göre; önce bir adet sıçan bir gece aç bırakıldı. Canlı ağırlığı tartıldıktan sonra gavaj yoluyla en düşük toksisite dozu $2000 \mathrm{mg} / \mathrm{kg}$ ekstrakt veridi ve tek başına ayrı bir kafese alındı bir gün süresince aralıklı olarak davranışları gözlemlendi. Ölüm gözlenmediği için (24saat) dört sıçan bir gece daha aç bırakıldı ve ağırlıkları tartıldı yine $2000 \mathrm{mg} / \mathrm{kg}$ dozunda ekstrakt verildi. Bu sıçanlar 24 saat gözlendi. Siçan ölümleri gözlenmediği için LD50 dozunun $2000 \mathrm{mg} / \mathrm{kg}$ ' dan büyük olduğu anlaşıldı. Daha sonra 5000 ve $10000 \mathrm{mg} / \mathrm{kg}$ test dozu gece boyunca aç bırakılan tek bir sıçana verildi. Sıçan ölümleri görülmediği için iki sıçan daha aynı prosedürden geçirildi. Bu sıçanlarda da 5000 ve $10000 \mathrm{mg} / \mathrm{kg}$ test dozlarında ölüm görülmedi. Böylece Arum rupicola bitki ekistresinin LD50 dozunun (5000 mg / kg veya 10000 $\mathrm{mg} / \mathrm{kg}$ ) daha büyük olduğu tespit edildi. Uygulamada 2000, 5000, $10000 \mathrm{mg} / \mathrm{kg}$ bitki ekstre dozlarının yaklaşı $1 / 10$ 'u $(100,200,400 \mathrm{mg} / \mathrm{kg})$ bu bitkinin oksidadtif strese karşın anti diyabetik etkisinin belirlenmesinde doz aralı̆̆ olarak kabul edildi [14].

\subsection{Deneysel tasarım}

Gece boyu 12 saat aç bırakılan 36 adet sıçan rastgele altı gruba (n=6) ayrıldı. İlk grup, normal kontrol (NK) sadece yem ve musluk suyu verildi. İkinci grup streptozotosin (tek doz-50 mg/kg, ip) ile deneysel diyabet oluşturuldu (DK). Üçüncü grup, diyabet+akarboz (20mg/ kg) (DAK) deneme süresince verildi. Dört, beş ve altıncı gruplardaki sıçanlar STZ ile diyabet oluşturulduktan sonra sırasıyla 100, 200 ve 400 $\mathrm{mg} / \mathrm{kg}$ [(DAR: diyabet+Arum ekstresi) (DAR100, DAR200, DAR400 mg/kg)] doz seviyelerinde Arum rupicola liyoflize ekstresi gavaj yolu ile 25 gün deneme süresince aynı saatlerde uygulandı. Normal kontrol grubu hariç diğer gruplardaki sıçanlar $0.1 \mathrm{M}$ sitrat tamponu (pH: 4.5) içinde çözünen $\mathrm{STZ}$, intraperitonal (ip) yolla tek doz $(50 \mathrm{mg} / \mathrm{kg})$ enjeksiyonla verilerek diyabet olmaları sağlandı. STZ uygulananan gruplarda uygulamadan 72 saat sonra sıçanların kan glukoz değerleri (Accu-Chek Go Roche, A.B.D) glukometre ile ölçüldü ve kan glukoz düzeyi $>200 \mathrm{mg} / \mathrm{dL}$ olan siçanlar diyabet olarak kabul edildi $[15,16]$.

\subsection{Kan ve doku örneklerinin alınması}

Deneme sonunda (25 gün) sıçanlar 5mg/100mg ketaminle anestezi edildi. Biyokimyasal analizlerde kullanılacak kan dokusu sıçan kalbinden steril plastik enjektörler yardımıyla alındı. Eritrosit paketleri oluşturuldu. Ayrıca sarkifiye edilen sıçanlardan karaciğer, beyin, ve böbrek dokuları alındıktan sonra homojenizasyon işlemine tabi tutuldu. Derin dondurucuda tüm dokular $-80^{\circ} \mathrm{C}$ 'de antioksidan enzim ve antioksidan madde içeriğinin (SOD, CAT, ve GSH) ve LPO'nun son ürünü olan MDA düzeyinin belirlenmesine kadar muhafaza altına alındı [17].

\subsection{Biyokimyasal analizler}

Süperoksit dismutaz (SOD) enzimi (EC: 1.15.1.1) aktivitesi Randox-Ransod enzim kiti (Randox Laboratories Ltd. GB) kullanılarak ölçülmüş ve UV $37{ }^{\circ} \mathrm{C}^{\prime}$ de $505 \mathrm{~nm}$ 'de ölçüldü. Bu metoda göre ksantin ve ksantin oksidaz reksiyonunda üretilen süperoksit anyon radikallerinin SOD tarafindan oksijene dönüştürülerek inhibe esasına dayanır [18]. Katalaz aktiviteleri, 240 nm'de $\mathrm{H}_{2} \mathrm{O}_{2}$ ayrışma hızının tespit edildiği yönteme göre belirlendi [19]. Eritrosit ve dokularda GSH seviyesi, doku supernetantlarında fosfat tamponu kullanılmasıyla redükte glutatyonda (GSH) sülfidril gruplarının DTNB 5,5'-ditiyobis (2-nitrobenzoik asit) ile reaksiyonu ile sarı renge dönüşmesi esasına dayalı spektrofometrik bir yöntemle ölçüldü [20]. Eritrosit ve dokularda MDA içeriği Jain ve arkadaşlarına göre belirlendi. Bu metodun prensibi TBA reaktivitesine dayanmaktadır [21].

\section{7. İstatistiksel analiz}


İstatistiksel Analizler Windows paket programı Minitab 13 (Minitab, State College, PA) kullanılarak gerçekleştirildi. Tüm veriler, ortalama \pm standart sapma (SD) olarak sunuldu. Grup ortalamaları arasındaki farkların belirlenmesinde tek yönlü varyans (ANOVA) tukey post hoc testi kullanıldı. Anlamlılık düzeyi $\mathrm{p}<0.05$ olarak kabul edildi.

\section{Bulgular ve Tartışma}

Bitki ekstresi uygulanan sıçanların kontrol grubuna göre karşılaştırıldığı eritrosit, beyin, böbrek, karaciğer SOD, CAT enzim aktivitesi ile GSH ve LPO'u son ürünü MDA düzeyi verileri Tablo 1 verilmiştir. Bu bulgulara göre eritrosit SOD aktivitesinin DAR3 grubunda DK grubuna göre anlamlı arttığı belirlendi $(\mathrm{p}<0.05)$. Bitki ekstre uygulanan tüm gruplarında beyin SOD aktivitesinin NK'e göre arttığı, böbrek DAR3 grubu karaciğer dokusunda ise hem DK'e hem de NK'e göre azaldığı belirlendi. $\mathrm{Bu}$ dokulardaki SOD aktivitesindeki değişimler anlamlı bulundu $(\mathrm{p}<0.05)$. SOD, oksijen metabolizmasının toksik etkilerine karşı savunma mekanizmasının en önemli enzimidir. Aşırı süperoksit mevcudiyeti SOD aktivitesinde farklılıklara neden olduğu bildirilmiştir [22]. SOD inhibisyonu, SOD enzim proteini sentezinde azalma veya enzim proteinlerinin fonksiyonel yapılarının aşırı üretilen serbest radikallerden geri dönüşümsüz bozulmasından kaynaklandığı bildirmiştir [23]. Hiperglisemide glukozun oto-oksidasyonun sonucu aşırı oksijen radikali üretilmesinden dolayı oksidatif strese neden olduğu düşünülmektedir [24]. Ayrıca, hipergliseminin eritrositlerde membran hasarından da sorumlu olduğu ileri sürülmüştür [25]. Diyabetik sıçanlarda CAT, Px ve SOD aktivitelerinin azaldığını bildirilmiştir. Bununla birlikte, bitki ekstresi tatbik edilen sıçanlarda bu enzimatik antioksidanların aktivitelerini geri kazandığı tespit edilmiştir [26]. Bu çalışmada DAR3 grubunda SOD aktivitesinde DK grubuna göre artışı bu bitkinin $400 \mathrm{mg} / \mathrm{kg}$ uygulandığı dozun diyabet kaynaklı serbest radikallerin etkilerini baskıladığı söylenebilir. Diyabetik sıçanlarda beyin dokusunda tüm uygulama gruplarında DK grubuna göre artmış SOD aktivitesinin muhtemelen azalmış oksidatif stres potansiyeli ile ilişkili olabilir [27]. Diyabetik DAR3 grubunda böbrek SOD enzim aktivitesinin azalmasında glikoz oto-oksidasyonu ve bu enzimlerin glikasyonu sonucunda aşırı üretilen serbest radikalleri süpürücü görevlerini yerine getirirken yoğun kullanımlarına bağlı olabilir [28].

Tablo 1'deki verilere göre eritrosit ve karaciğerin tüm uygulama grupları ile beyin DAR2 ve DAR3 gruplarında CAT aktivitesinde NK ve DK'e göre azalışı anlamlı bulundu $(\mathrm{p}<0.05)$. Tüm ekstere uygulama gruplarının böbrek dokularında, beyin dokusunda DAR3 grubunda CAT aktivitesi DK'e göre anlamlı bir artış belirlendi $(\mathrm{p}<0.05)$. Diyabetik araştırmalarda, oksidatif strese karşı SOD ve CAT aktivitesinin ölçülmesi bu iki enzimin savunma hattını ilk safhasını oluşturdukları için önemlidir. CAT, bir hemoproteindir. Oldukça önemli oranlarda $\mathrm{H}_{2} \mathrm{O}_{2}$ 'nin su ve oksijene dönüştürerek detoksifikasyon işlevi gördüğü bilinmektedir [29-30]. Antioksidan enzim azalmış aktivitelerinin ileri derecede glikoz oksidasyonu ile ilişkili olduğu ve bununda serbest radikal üretimini tetiklediği bildirilmiştir [31]. Diğer yandan SOD, GPx ve CAT aktivitelerinin dokudan dokuya değişebileceği yapılan çalışmalarla rapor edilmiştir [32]. Bu çalışmada, bitki ekstresi uygulanan gruplarda eritrosit, karaciğer ve beyin CAT aktivitesinin artmış ROS üretimine bağlı savunmada yetersiz kaldığı söylenebilir. Ancak böbrek tüm uygulama gruplarında ve beyin DAR1 grubunda CAT aktivite artışı DK ve NK'e göre antioksidan savunma hattında ROS üretimini engellediğide söylenebilir.

Eritrosit GSH içeriği tüm uygulama gruplarında NK'e göre anlamlı azalırken, DAR1 grubundaki artiş DK'e göre anlamlı bulundu ( $\mathrm{p}<0.05)$. Beyin dokusu GSH içeriği DAR2 grubunda NK'e göre anlamlı azalırken, diyabetik gruplarda DAR2 ve DAR3 GSH düzeyindeki artış ve DAR3 grubu GSH düzeyindeki düşüş anlamlı bulundu (p <0.05). Ekstre verilen sıçanların karaciğer GSH düzeylerindeki azalış hem kontrol hem de diyabetik gruplarda anlamlı bulundu $(\mathrm{P}<0.05)$.

GSH, serbest radikalleri temizlemeye yardımcı olan glutatyon redüktaz tarafından üretilen hücre içi bir antioksidandır [33]. Diyabetik oksidatif strese bağlı GSH düzeylerindeki azalışlar antioksidan savunma sistemi için önemli bir gösterge olarak kabul edilir [34]. GSH, serbest radikallere karş1 süpürücü etkisi yanında GPx içinde ko-substrat olarak görev yapan endojen bir antioksidandır. Fizyolojik şartlarda, süperoksit, hidroksil ve tekli oksijeni radikallerini doğrudan temizleyici güce sahiptir [35]. Diyabetik gruplarda enzim aktivitesinde ve antioksidan madde içeriğinde aşırı serbest radikal üretimine bağlı görülen azalışların nedeni, antioksidan enzim aktivitesinin yoğun çalışmasından ve antioksidan madde içeriğinin ise aşırı kullanılmasından kaynaklandığı söylenebilir. Ciddi stres 
koşullarında, bu sistem hücre içindeki koruyucu etkisini kaybeder. Artmış GSH içeriği, STZ kaynaklı diyabetik sıçanlarda azalmış antioksidan enzim aktivitesi ve içeriğinin bozulmuş redoks döngüsüne karş1 koruyucu bir rol üstlendiğini düşündürmektedir.

Tablo 1. göre eritrosit MDA içeriğindeki düşüş kontrol ve ekstre verilen tüm gruplarda anlamlı bulundu ( $\mathrm{p}<0.05)$. Beyin MDA içeriğinin DAR3 grubunda artışı kontrol ve ekstre gruplarına göre önemli bulundu ( $\mathrm{p}<0.05$ ). Böbrek MDA içeriğindeki kontrol ve ekstre verilen tüm gruplardaki artış1 anlamlı bulunurken karaciğerde ise MDA içeriğindeki azalış, DAR1 grubunda DK grubuna göre, DAR2, DAR3 gruplarında ise NK ve DK'e göre anlamlı bulundu ( $\mathrm{p}<0.05)$.

Lipid peroksidasyon, oksidatif stres kaynaklı aşırı serbest radikallerin üretilmesi ve bu radikallerin hücre zarlarında çoklu doymamış yağ asitleriyle reaksiyona girerek oluşturduğu bir süreci tanımlar. Bu süreç, membran viskozitesini azaltarak, membran potansiyelinin negatif etkilenmesine, hidrojen ve diğer iyonların geçirgenliğinin aratmasına ve sonucunda ise hücre hasarlarına neden olmaktadır [36]. Oldukça yüksek reaktifiteye sahip olması ve çift fonksiyonlu niteliği olan MDA, eritrositlerin membran hasarlarında LPO'un iyi tanımlanmış bir ürünüdür. Membran yapısında fosfolipidleri ve proteinleri çapraz bağlayarak fonksiyonel işlevlerini bozduğu bildirilmiştir [37]. Diyabetik sıçanlarda artmış MDA seviyesi ile birlikte antioksidan enzim ve moleküllerin azalmış aktivitesi muhtemelen oksidatif stres ve azalmış antioksidan savunma potansiyeli ile ilişkili olabilir. Yapılan bir araştırmada, hiperlipidemik, hiperglisemik komplikasyonları ile ilişkili oksidatif stres sonucunda indüklenmiş lipid peroksidasyonun hücre hasarlarına neden olduğu bildirilmiştir [38]. STZ'nin neden olduğu diyabetik sıçanlarda MDA seviyesinin yükselmesi ve antioksidan savunma unsurlarında önemli azalışlar (SOD, CAT, GSH gibi) benzer çalışmalarda rapor edilmiştir [39, 40]. Arum rupicola ekstresi verilen gruplarda lipit peroksidasyona karşı sağlanan korunma, dokularda bu bitki bileşenlerinin serbest radikallere karşı antioksidan aktiviteye destek sağladığı doğrultusunda yorumlanabilir. Bu sonuçlar, bitki ekstrelerinin diyabetik komplikasyonlarda iyileştirici etkisinin araştırıldığı serbest radikal temizleyici antioksidan moleküllerinde eşzamanlı artışı ile birlikte MDA seviyesinin de azaldığını bildiren birçok çalışma ile paralellik göstermektedir [41, 42, 43].

\section{Sonuç ve Öneriler}

Bu çalışmada, halk arasında hem gıda olarak tüketilen hem de diyabet ve birçok hastalığın tedavisinde kullanılan Arum rupicola toprak üstü gövde ve yaprak ekstresinin diyabet kaynakl1 oksidatif stres üzerindeki etkisini araştırılması amaçlanmıştır. Bitki ekstresinin antioksidan kapasite üzerine etkilerinin belirlenmesinde farklı dokular arasında antioksidan enzim aktivitelerinde ve GSH düzeylerinde dalgalanmalar olduğu, ancak genel itibariyle bitki ekstresinin uygulama dozuna bağlı olarak antioksidan kapasiteye katkısının olduğu söylenebilir. Çoklu bitkisel formulasyonla yapılan bir çalışmada, bitkilerin zengin alkaloitler, tanenler ve flavonoidler, glikozitler bileşenlerinden dolayı anti-enflamatuar ve antioksidan etkileriyle diyabet komplikasyonlarına karşı iyileştirici etkilere sahip oldukları rapor edilmiştir[44, 45].

Tablo 1. Arum rupicola liyofilize ekstresi uygulanan deney gruplarında antioksidan savunma ve lipit peroksidasyonu üzerine etkisi. 


\begin{tabular}{|c|c|c|c|c|c|c|c|}
\hline \multicolumn{8}{|c|}{ Gruplar } \\
\hline & & NK & DK & DAK & DAR1 & DAR2 & DAR3 \\
\hline \multicolumn{2}{|l|}{ Dokular } & Ortalama + SD & Ortalama + SD & Ortalama + SD & Ortalama + SD & Ortalama + SD & Ortalama + SD \\
\hline \multirow[t]{4}{*}{$\begin{array}{l}\text { Eritrosit } \\
(\mathrm{U} / \mathrm{ml})\end{array}$} & SOD & $2258.46 \pm 16.79$ & $2245.59 \pm 16.08$ & $2255.18 \pm 5.26$ & $2252.18 \pm 13.15$ & $2242.14 \pm 10.13$ & $2260.92 \pm 9.56^{\mathrm{b}}$ \\
\hline & CAT & $229.77 \pm 6.12$ & $213.57 \pm 9.86^{\mathrm{a}}$ & $219.72 \pm 6.9^{\mathrm{a}}$ & $145.73 \pm 2.11^{\mathrm{ab}}$ & $159.13 \pm 7.41^{\mathrm{ab}}$ & $183.70 \pm 8.2^{\mathrm{ab}}$ \\
\hline & GSH & $0.87 \pm 0,04$ & $0.64 \pm 0.05^{\mathrm{a}}$ & $0.64 \pm 0.02^{\mathrm{a}}$ & $0.71 \pm 0.06^{\mathrm{ab}}$ & $0.62 \pm 0.01^{\mathrm{a}}$ & $0.61 \pm 0.02^{\mathrm{a}}$ \\
\hline & MDA & $6.04 \pm 0.33$ & $9.17 \pm 0.16^{\mathrm{a}}$ & $3.67 \pm 0.78^{\mathrm{ab}}$ & $4.64 \pm 0.75^{\mathrm{ab}}$ & $2.91 \pm 0.54^{\mathrm{ab}}$ & $4.31 \pm 0.33^{\mathrm{ab}}$ \\
\hline \multirow{4}{*}{$\begin{array}{l}\text { Beyin } \\
\text { (U/g) }\end{array}$} & SOD & $2158.00 \pm 28.81$ & $2057.20 \pm 13.50^{\mathrm{a}}$ & $2161.91 \pm 28.81^{b}$ & $2152.3 \pm 24.03^{\mathrm{b}}$ & $2132.36 \pm 19.71^{b}$ & $2156.35 \pm 28.77^{b}$ \\
\hline & CAT & $117.25 \pm 4.74$ & $92.13 \pm 5.08^{\mathrm{a}}$ & $74.26 \pm 9.80^{\mathrm{ab}}$ & $119.49 \pm 7.24^{b}$ & $75.93 \pm 11.9^{a b}$ & $78.17 \pm 8.10^{\mathrm{ab}}$ \\
\hline & GSH & $4.94 \pm 0.15$ & $3.21 \pm 0.22^{\mathrm{a}}$ & $3.57 \pm 0.23^{\mathrm{ab}}$ & $5.14 \pm 0,50^{\mathrm{b}}$ & $4.77 \pm 0.32^{\mathrm{a}}$ & $5.29 \pm 0.13^{\mathrm{ab}}$ \\
\hline & MDA & $6.06 \pm 0.38$ & $6.01 \pm 0.47$ & $7.36 \pm 0.37^{\mathrm{ab}}$ & $6.04 \pm 0.73$ & $5.98 \pm 0.31$ & $9.08 \pm 0.56^{\mathrm{ab}}$ \\
\hline \multirow{4}{*}{$\begin{array}{l}\text { Böbrek } \\
\text { (U/g) }\end{array}$} & SOD & $2178.53 \pm 22.92$ & $2150.88 \pm 24.91^{\mathrm{a}}$ & $2139.07 \pm 23.27^{\mathrm{a}}$ & $2171.75 \pm 23.27$ & $2162.22 \pm 20.89$ & $2136.57 \pm 24.54^{\mathrm{a}}$ \\
\hline & CAT & $95.15 \pm 1.57$ & $80.60 \pm 5.21^{\mathrm{a}}$ & $109.81 \pm 4.45^{\mathrm{a}}$ & $103.76 \pm 6.20^{\mathrm{ab}}$ & $121.44 \pm 7.93^{\mathrm{ab}}$ & $116.09 \pm 5.45^{\mathrm{ab}}$ \\
\hline & GSH & $2.25 \pm 0.08$ & $2.01 \pm 0.07^{\mathrm{a}}$ & $2.04 \pm 0.08^{\mathrm{a}}$ & $2.12 \pm 0.10^{\mathrm{ab}}$ & $2.18 \pm 0.07^{b}$ & $1.89 \pm 0.07^{\mathrm{ab}}$ \\
\hline & MDA & $10.20 \pm 0.38$ & $11.26 \pm 0.16^{\mathrm{a}}$ & $15.54 \pm 0.98^{\mathrm{ab}}$ & $16.82 \pm 0.42^{\mathrm{ab}}$ & $15.03 \pm 0.18^{\mathrm{ab}}$ & $14.89 \pm 0.50^{\mathrm{ab}}$ \\
\hline \multirow{4}{*}{$\begin{array}{l}\text { Karaciğer } \\
(\mathrm{U} / \mathrm{g})\end{array}$} & SOD & $2034.16 \pm 32.49$ & $2029.52 \pm 14.67$ & $1937.75 \pm 41.74^{\mathrm{ab}}$ & $1930.30 \pm 21.32^{\mathrm{ab}}$ & $1958.02 \pm 46.35^{\mathrm{ab}}$ & $2021.14 \pm 42.26$ \\
\hline & CAT & $446.70 \pm 1.80$ & $358.75 \pm 6.30^{\mathrm{a}}$ & $149.36 \pm 22.73^{a b}$ & $256.85 \pm 12.60^{\mathrm{ab}}$ & $173.09 \pm 22.26^{\mathrm{ab}}$ & $245.68 \pm 26.30^{\mathrm{ab}}$ \\
\hline & GSH & $5.02 \pm 0.05$ & $3.08 \pm 0.11^{\mathrm{a}}$ & $2.46 \pm 0.08^{\mathrm{ab}}$ & $1.48 \pm 0.10^{\mathrm{ab}}$ & $1.47 \pm 0.11^{\mathrm{ab}}$ & $1.53 \pm 0.17^{\mathrm{ab}}$ \\
\hline & MDA & $8.11 \pm 0.56$ & $12.20 \pm 0.41^{\mathrm{a}}$ & $8.62 \pm 0.34^{b}$ & $7.97 \pm 0.17^{b}$ & $5.67 \pm 0.17^{\mathrm{ab}}$ & $6.09 \pm 0.54^{\mathrm{ab}}$ \\
\hline
\end{tabular}

a Kontrol grubu ile DK, DAK, DAR1, DAR2 ve DAR3 grupları arasındaki fark anlamlıdır ( $\mathrm{p} \leq 0.05)$.

b DK grubu ile DAK, DAR-1, DAR-2 ve DAR-3 grupları arasındaki fark anlamlıdır $(\mathrm{p} \leq 0.05)$.

\section{Teșekkür}

Yüzüncü Yı1 Üniversitesi Bilimsel Araştırma Projeleri Başkanlığı tarafindan desteklenmiştir (FYL2016-5038).

\section{Kaynaklar}

[1] Jadidoleslami M., Abbasnejad M., Shahraki M.R. 2010. The survey of Aloe vera aqueous extract and glibenclamid interaction on blood glucose, LFT and lipids diabetic induced male rats by streptozotocin. Journal of Rafsanjan University of Medical sciences, 9 (3): 185-194.

[2] Mokhtari M., Mohammadi J. 2012. The effect of hydroalcoholic extracts of Prangos ferulacea on blood factors of kidney and liver functions in diabetic male wistar rats. Journal of Fasa University of Medical Sciences, 2 (3): 174-180.

[3] Shirali S., Bathaei S.Z., Nakhjavani M., Ashoori M.R. 2012. Effects of saffron (Crocus sativus L.) aqueous extract on serum biochemical factors in streptozotocin-induced diabetic rats. Iranian Journal of Medicinal and Aromatic Plants 28(2) : 293-308.

[4] Bhattacharya S., Manna P., Gachhui R., Sil P.C. 2013. D-Saccharic acid 1, 4-lactone protects diabetic rat kidney by ameliorating hyperglycemia-mediated oxidative stress and renal inflammatory cytokines via NF- $\mathrm{BB}$ and PKC signaling. Toxicology and applied pharmacology, 267 (1): 16-29.

[5] Brownlee M. 2005. The pathobiology of diabetic complications: a unifying mechanism. Diabetes, 54 (6): 1615-1625.

[6] Nishikawa T., Edelstein D., Du X.L., Yamagishi S., Matsumura T., Kaneda Y., Yorek M.A., Beebe D., Oates P.J., Hammes H.P., Giardino I., Brownlee M. 2000. Normalizing mitochondrial 
superoxide production blocks three pathways of hyperglycaemic damage. Nature, 404 (6779): 787-90.

[7] Yamagishi S.I., Edelstein D., Du X.L., Brownlee M. 2001. Hyperglycemia potentiates collageninduced platelet activation through mitochondrial superoxide overproduction. Diabetes, 50 (6): 1491-1494.

[8] Bayani U., Singh A.V., Zamboni P., Mahajan R.T. 2009. Oxidative Stress and Neurodegenerative Diseases: A Review of Upstream and Downstream Antioxidant Therapeutic Options. Curr Neuropharmacol. 7 (1): 65-74.

[9] Rahimi-Madiseh M., Heidarian E., Kheiri S., Rafieian-Kopaei M. 2017. Effect of hydroalcoholic Allium ampeloprasum extract on oxidative stress, diabetes mellitus and dyslipidemia in alloxaninduced diabetic rats. Biomedicine \& pharmacotherapy, 86: 363-367.

[10] Rahimi-Madiseh M., Gholami-Arjenaki M., Bahmani M., Mardani G., Farzan M., RafieianKopaei M. 2016. Evaluation of minerals, phenolics and anti-radical activity of three species of Iranian berberis fruit. Der Pharma Chemica, 8 (2): 191-197.

[11] Güneş S., Savran A., Paksoy M.Y., Çakılc1oğlu U. 2018. Survey of wild food plants for human consumption in Karaisalı (Adana-Turkey). Indian Journal of Traditional Knowlwedge 17 (2): 290-298.

[12] Dalar A. 2018. Plant Taxa Used in the Treatment of Diabetes in Van Province, Turkey. International Journal of Secondary Metabolite, 5 (3): 171-185.

[13] Kaisoon O., Konczak I., Siriamornpun S. 2012. Potential health enhancing properties of edible flowers from Thailand. Food Res. Int., 46 (2). 563-571.

[14] Organization for Economic Co-operation and Development (OECD) guideline for testing of chemicals, 20014. Acute Oral Toxicity-Acute Toxicity (425).

[15] Hemalatha S., Wahi A.K., Singh P.N., Chansouria J.P.N. 2004. Hypoglycemic activity of withania coaculants dunal in streptozotocin induced diabetic rats. Journal of Ethnopharmacolgy, 93: 261-264.

[16] Kanitkar M., Bhonde R. 2004. Existence of islet regenerating factors within the pancreas. The Review of Diabetic Studies, 1(4), 185-192.

[17] Xia E., Rao G., Remmen H.V., Heydari A.R., Richardson A. 1994. Activities of antioxidant enzymes in various tissues of male fischer 344 rats are altered by food restriction. J. Nutr., 125: 195-201

[18] McCord J.M., Fridovich I. 1969. Superoxide dismutase an enzymic function for erythrocuprein (hemocuprein). Journal of Biological chemistry, 244 (22): 6049-6055.

[19] Aebi H. 1984. Catalase in Vitro. In Methods in Enzymology; Academy Press: New York, NY, USA, pp. 121-126

[20] Beutler E. 1963. Improved method for the determination of blood glutathione. Journal of Laboratory and Clinical Medicine, 61: 882-888.

[21] Jain S.K., McVie R., Duett J., Herbst J.J. 1989. Erythrocyte membrane lipid peroxidation and glycosylated hemoglobin in diabetes. Diabetes, 38 (12): 1539-1543.

[22] Bondy S.C. 1992. Ethanol toxicity and oxidative stress. Toxicology letters, 63 (3): 231-241.

[23] Husain K., Scott B.R., Reddy S.K., Somani S.M. 2001. Chronic ethanol and nicotine interaction on rat tissue antioxidant defense system. Alcohol, 25 (2): 89-97.

[24] Yang H.L., Chen S.C., Chang N.W., Chang J.M., Lee M. L., Tsai P.C., Hseu Y.C. 2006. Protection from oxidative damage using Bidens pilosa extracts in normal human erythrocytes. Food and Chemical Toxicology, 44 (9): 1513-1521

[25] Jain S.K. 1989. Hyperglycemia can cause membrane lipid peroxidation and osmotic fragility in human red blood cells. Journal of Biological Chemistry, 264 (35): 21340-21345.

[26] Maiti R., De D., Ghosh D. 2018. Antıdiabetic effect of n-hexane fraction of hydro-methanolic extract of Tamarindus indica Linn. Seed in streptozotocin-1nduced diabetic rat: a correlative approach with in vivo and in vitro antioxidant activities. International journal of pharmaceutical sciences and research, 9 (5): 1821-1830.

[27] Jangir R.N., Jain G.C. 2017. Evaluation of antidiabetic activity of hydroalcoholic extract of Cassia fistula Linn. pod in streptozotocin-induced diabetic rats. Pharmacognosy Journal, 9 (5):599-605. 
[28] Almeida D.A.T.D., Braga C.P., Novelli E.L.B., Fernandes A.A.H. 2012. Evaluation of lipid profile and oxidative stress in STZ-induced rats treated with antioxidant vitamin. Brazilian Archives of Biology and Technology, 55 (4): 527-536

[29] Taheri E., Djalali M., Saedisomeolia A., Moghadam A.M., Djazayeri A., Qorbani M. 2012. The relationship between the activates of antioxidant enzymes in red blood cells and body mass index in Iranian type 2 diabetes and healthy subjects. Journal of Diabetes \& Metabolic Disorders, 11 (1): $1-5$.

[30] Molehin O.R., Oloyede O.I., Adefegha S.A. 2018. Streptozotocin-induced diabetes in rats: effects of white butterfly (Clerodendrum volubile) leaves on blood glucose levels, lipid profile and antioxidant status. Toxicology mechanisms and methods, 28 (8): 573-586.

[31] Sies H. Glutathione and its role in cellular functions. Free Radic Biol Med 1999;27: 916-21.

[32] Wu G., Fang Y. Z., Yang S., Lupton J. R., Turner N.D. 2004. Glutathione metabolism and its implications for health. The Journal of nutrition, 134(3), 489-492.

[33] Jayachandran M., Vinayagam R., Ambati R. R., Xu B., Chung S.S. M. 2018. Guava leaf extract diminishes hyperglycemia and oxidative stress, prevents $\beta$-cell death, inhibits inflammation, and regulates NF-kB signaling pathway in STZ induced diabetic rats. BioMed research international, 2018: 1-14.

[34] Aragno M., Brignardello E., Tamagno E., Gatto V., Danni O., Boccuzzi G. 1997. Dehydroepiandrosterone administration prevents the oxidative damage induced by acute hyperglycemia in rats. Journal of Endocrinology, 155 (2): 233-240.

[35] Tiwari B.K., Abidi A.B., Rizvi S.I., Pandey K.B. 2018. Effect of oral supplementation of composite leaf extract of medicinal plants on biomarkers of oxidative stress in induced diabetic Wistar rats. Archives of physiology and biochemistry, 124 (4): 361-366.

[36] Demir E., Keser S., Yılmaz Ö. 2016. Acı Badem Yağının Streptozotosin Kaynaklı Diyabetik Sıçanların Serum ve Eritrositlerindeki Bazı Biyokimyasal Parametreler Üzerindeki Etkileri. Karaelmas Fen ve Mühendislik Dergisi, 5 (2): 61-67.

[37] Padayatty S.J., Katz A., Wang Y., Eck P., Kwon O., Lee J.H., Levine M. 2003. Vitamin C as an antioxidant: evaluation of its role in disease prevention. Journal of the American college of Nutrition, 22 (1): 18-35.

[38] Tas S., Tas B., Bassalat N., Jaradat N. 2018. In-vivo, hypoglycemic, hypolipidemic and oxidative stress inhibitory activities of Myrtus communis L. fruits hydroalcoholic extract in normoglycemic and streptozotocin-induced diabetic rats. Biomedical Research, 29 (13): 2727-2734.

[39] Çomu F.M., Polat Y., Özer A., Erer D., Kirişçi M., Dursun A.D., Arslan, M. 2017. The Effect of Picroside-2 on Erythrocyte Deformability and Lipid Peroxidation in Streptozotocin-Induced Diabetic Rats Subjected to Left Anterior Descending Artery-Ischaemia Reperfusion. Gazi Medical Journal, 28 (2): 927-931.

[40] Yang H.L., Chen S.C., Chang N.W., Chang J.M., Lee M.L., Tsai P.C., Hseu Y.C. 2006. Protection from oxidative damage using Bidens pilosa extracts in normal human erythrocytes. Food and Chemical Toxicology, 44 (9): 1513-1521.

[41] Gomathi D., Ravikumar G., Kalaiselvi M., Devaki K., Uma C. 2013. Efficacy of Evolvulus alsinoides (L.) L. on insulin and antioxidants activity in pancreas of streptozotocin induced diabetic rats. Journal of Diabetes \& Metabolic Disorders, 12 (1): 39.

[42] Liu M, Song X, Zhang J, Zhang C, Gao Z, Li S, Jing H., Ren Z., Wang S., Jia L. 2017. Protective effects on liver, kidney and pancreas of enzymatic- and acidic-hydrolysis of polysaccharides by spent mushroom compost (Hypsizigus marmoreus). Sci Rep., 7: 43212.

[43] Hassan S.K., El-Sammad N.M., Mousa A.M., Mohammed, M.H., Farrag A.E.R.H., Hashim A. N.E., Nawwar M.A.E.M. 2015. Hypoglycemic and antioxidant activities of Caesalpinia ferrea Martius leaf extract in streptozotocin-induced diabetic rats. Asian Pacific Journal of Tropical Biomedicine, 5 (6): 462-471.

[44] Jangir RN, Jain GC. 2016. Antidiabetic and antioxidant potential of hydroalcoholic extract of Moringa oleifera leaves in streptozotocin-induced diabetic rats. Eur J Pharm Med Res., 3: 438450. 
[45] Majumder P., Paridhavi M. 2019. A Novel Poly-herbal Formulation Hastens Diabetic Wound Healing with Potent Antioxidant Potential: A Comprehensive Pharmacological Investigation. Pharmacognosy Journal, 11 (2): 324-331. 